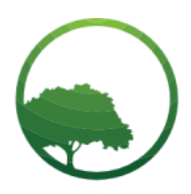

Research in Business \& Social Science

\title{
Perception of host communities on the sustainability of the corporate social responsibility programs of Philippine mining companies: A mixed-method approach
}

\author{
Jackie Lou O. Raborar@a, Elizabeth O. Recio b \\ a,bThe Graduate School,University of Santo Tomas, Manila, Philippines
}

Crossref

\begin{tabular}{l} 
A R T I C L E I N F O \\
\hline Article history: \\
Received 03 January 20 \\
Received in revised form 05 Feb 20 \\
Accepted 07 Feb 20 \\
\hline Keywords: \\
Corporate Social Responsibility \\
Host Communities \\
Mining, Sustainable Development \\
JEL Classification: \\
O15, P36
\end{tabular}

\begin{abstract}
A B S T R A C T
The objective of this research is to provide the necessary framework and recommendations to help just completed Corporate Social Responsibility Programs of mining companies and eventually improve their existing implementation of SDMP for the benefit of the host communities. The researcher used the mixed-method research design wherein both the qualitative and quantitative approaches were utilized to better understand and validate the results. For the quantitative approach, survey questionnaires were administered to 376 respondents from the host communities during site visits. On the other hand, the qualitative approach used to interview and FGD to the various community representatives of the same host communities. The results revealed that the respondents are aware of the $1.5 \%$ budget of mining companies for SMDP and mining companies have adequate and professional personnel that run the operations of SMDP projects. However, it was found that mining companies have an incomplete set of SMDP documents kept in their offices. The results also revealed that the respondents of the five Barangays have strongly agreed that there are social issues raised against the mining project but they disagreed on the stakeholder groups are satisfied with the process.
\end{abstract}

(C) 2020 by the authors. Licensee BSC International Publishing, Istanbul, Turkey. This article is an open access article distributed under the terms and conditions of the Creative Commons Attribution (CC BY) license (http://creativecommons.org/licenses/by/4.0/).

\section{Introduction}

In this global market, the demand and competition for mining products is very high. However, the adverse impact to the environment and society has been become very prevalent. In the World Bank report, there are social issues that still unaddressed; there is the issue of how the benefits are allocated within the host communities, and it's a challenge to mining companies to behave responsibly specially with their relationship to the host communities. United Nations has committed to "leaving no one behind" in an effort to help countries promote inclusive growth and achieve the Sustainable Development Goals (SDGs). The Philippine government, through the Department of Environment and Natural Resources (DENR), has established the Republic Act No. 7942, 'or the Philippine Mining Act of 1995. The Development of Mining Communities has been emphasized in Chapter XIV Section 134-136F of its Consolidated Administrative Order 2010-21. The Social Development and Management Program (SDMP) is mandated to be implemented by all operating mining/quarrying companies to support the education, health, social, cultural and economic aspects in the host communities. Since its implementation in 2011, it was noted that there are inconsistencies in the implementation of the Program.

Over the years, there has been a steady generation of data regarding the practices mining companies are employing in their implementation of the SDMP. At the same time, major challenges on their implementation have aired by some sectors, affecting the achievement of the objectives of the Program particularly that of making the host and neighboring barangays become independent and resource-based communities. Supporting the necessary financial aids from the mining companies does not guarantee a successful program, project and activities implemented. The mining company still needs the active participation of the community and that is

* Corresponding author. ORCID ID: 0000-0002-7418-6931 
the most essential part of community development. People are the center of development in the implementation of SDMP and so the effort and resources invested shall be translated into the overall benefits for the community.

The study was conducted to determine the level of awareness of the host communities and the perception of the respondents with regard to the sustainability of the different SMDP projects being implemented by mining companies.

The results of the study will be of great use to the mining companies in evaluating the effectiveness of its SMDP programs; the government being the regulator which ensures strict implementation of the law; anf the host communities being the recipients of these programs.

\section{Literature Review}

\section{The Mining Industry in the Philippines}

The 2015 Annual Survey of Philippine Business and Industry (ASPBI) gathered the data last April 2016 with the reference from the year 2015. Data ware at a countrywide level, then enterprise sub-class, then the 5-digit 2009 Philippine Standard Industrial Classification (PSIC). These data clearly show that the mining industry is an integral part of the economy as a whole. As of 2017, the contribution of the mining industry to Philippine gross domestic product (GDP) was an all time high of 30306.94 PHP Million. It was noted that investors gained confidence in investing in the country during that time.

\section{Mining Industry and Poverty}

According to the study about Extractive industries and poverty entitled "A Review of Recent Findings and Linkage Mechanisms" by Gamu, et al. (2015), there is a lack of uniformity with regard to the extent of contribution of mining companies to reduce poverty. It proved that large-scale mining companies contribute to the reduction of poverty (Gamu, et al., 2015). However, cross national studies have found that poverty increased rather than decreased because of unfair practices (Gamu, et al., 2015). Subsequent research using panel data other than cross-sectional data (Davis \& Cordano, 2013) found no measured significance whether in the reduced or increased correlation between mining and poverty (Gamu, et. al., 2015).

Obed-Adonteng-Kissi (2017) studied Ghana Prestea and utilized mixed-method of research to obtain enough data about the impact of the mines compensation package on poverty reduction. The result was, the compensation package of mining companies to alleviate poverty of the poor farmers that were affected by mining operations was so poorly designed due to mismatch to the value of the farmlands. It was reported that the local government in Ghana was not being supportive to fight for their rights while they continued to attract foreign investors.

In the circumstance that compensation package does not match the needs of the affected communities, there are some positive effects gained from the mining companies in the form of infrastructure, jobs, some livelihood programs, but usually employment opportunities are the major benefit to the local communities. Debates arose to whether monetary compensation is not suitable to change the standard of living of the poor communities (Adonteng-Kissi, 2017).

A study about the mining development, income growth, and poverty alleviation conducted by Ge and Lei (2013) using the SAM approach confirmed that mining activities benefits households in the high- and middle-income households. However, in the lowincome household in rural areas, it had less contribution for the increase in income. Therefore, the poor became poorer because only the high- and medium-income households benefitted from the mining operations. It is suggested that the government should pay more attention of implementing poverty alleviation programs to the less developed communities with low income, education and trainings support so that they can work and be employed by the mining companies in the future (Ge \& Lei, 2013).

Marginalization is the cause of community resistance as it is a kind of exclusion whereby people were eliminated from the benefits they can be derived from the mining operations (Conde \& Billion, 2017). Based on the study of Conde and Billon (2017), people of the communities are being neglected in terms of provision of public services. Another form of marginalization is the exclusion of the same in any decision making because they are less than capacitated to participate (Ballard \& Banks, 2003; Bebbington, 2014; Robbins, 2004). Another factor is the dependency of the local communities that has created unusual trends. People find it difficult to survive when the mine ceases its operations (Fisher, 2007; Conde \& Billon, 2017). The place and territory, alliances, distrust also contributes to the community resistance against mining.

The kind of mining projects and degree of impact are partly determined by its place, the availability of resources, and the process of extraction of minerals. The processing differs with regard to what type of minerals to be extracted, the pollution and toxicity that can be derived from the mining operation is one of the reasons why people resist, especially if they are highly-dependent on their livelihood, like mine wastes that affect their farmland and the water contamination (Conde \& Billon, 2017; Prior, et al., 2012). This can really affect not only their lifestyle, but also the cultural traditions and internal relations (Conde \& Billion, 2017; Perreault, et al., 2012).

A study conducted in the Philippines by William N. Holden from the year 2004-2012 and published last 2015, found out that Philippines can be vulnerable to disasters as it is surrounded by bodies of water and prone to severe weather conditions. Numbers of spills happened, and it caused the destruction of at least $90 \%$ of the livelihood of the local communities specifically in the Bicol 
Region (Holden, 2015). But even without the ravaging of typhoons, large-scale mining operations have had negative effects to the environment (Holden, 2015). That is stress, trauma, and down time (Conde \& Billion, 2017).

Remote locations is a factor wherein mining project locations are bereft of government presence and so the regulators comes only to the mining the concern of the civil society group opposing mining companies (Holden \& Jacabson, 2009; Holden, 2015). Another consideration is the displacement of the whole community to a new place as this causes companies, and this can lead to abuse (Conde $\&$ Billion, 2017). Haslam and Tanimoune (2016) found that people in the remote areas do not have the power to voice out their concerns due to weak or lack of government presence and results to increase in conflict (Ballard \& Banks, 2003; Conde \& Billon, 2017; Fox, 2015; Martinez Alier, 2003; Muradian, et al., 2003).

\section{Corporate Social Responsibility of Philippine Mining Companies}

20 years ago, people did not care much about social responsibility. It was in 1964 when the first CSR organization was formed by the development business group in Venezuela and organized a common foundation named as the Philippine Business for Social Progress (PBSP) which as of today, is one of the flourishing NGOs in the world (Corporate Social Responsibility: Implications for Small and Medium Enterprises in Developing Countries, United Nations Industrial Development Organization, 2002).

Corporate Social Responsibility (CSR) is often considered mandatory in the mining industry since its operation has a direct impact to the environment and local communities. The recognition toward CSR is increasing since it has a benefit to the economic, environment, and society (Govidan, Kannan, \& Shakar, 2014). Before, mining companies did not care about exploiting the land, and after using the area; they transferred to other areas to continue mining (Govindan, Kannan \& Shakar, 2014).

When CSR is now being introduced and mining company starts to integrate into their business model its helps to manage community relations properly. Multinational corporations make use of CSR in constituting global processes in local places so their actions are creating, sustaining and reinforcing the local communities (Turker, 2018).

Although many positive views about CSR are available, there were findings of many researches about the weaknesses of CSR when it comes to implementation. In Ghana, mining firms do various CSR programs for the local community but have not converted to sustainable development due to persistence complains about social, environmental and economic backlash (Zamorshchikova, 2016). The negligence to manage disparity and methods present challenges moving forward to the number of studies and have shown that corporate investments in communities by mining companies result in corporate-controlled development instead of community-led development (Wilson, 2015).

CSR may cause dependency rather than capacity if it is not aligned to the principles of people empowerment and sustainable development (Essah \& Andrews, 2016). Mining can only achieve sustainability if both parties get advantages. Social license to operate is mandatory for the mining companies; it is a major rope of corporate social responsibility (Owen \& Kemp, 2013). The idea of just getting the license to operate and not considering the public consent may affect its financial performance (Wilson, 2015).

\section{Community development in the mining industry}

According to the study of Conde and Billion (2017), the conflict between mining companies and the community has been increasing. Throughout the years, some conflict was not resolved and continues to worsen due to lack of trust and participation of the communities in any decision-making process (Arsel, et al., 2016; Bebbington, 2012; Conde \& Billion, 2017; Engles \& Dietz, 2017). Latin America has the most related conflicts in the late 2000s (CIEL, 2010; Perez Rincon, 2015). The problems showed the rise of environmentalists killed across the world.

Many countries incorporate community development in their policies and laws, in order to ensure the reversal of the negative impact of mining activities (Dupuy, 2014). The mining industry in some countries is the major source of their revenue through foreign exchange (Dupuy, 2014). Previous studies mentioned that global norms, especially in the mining industry, obviously consider the higher regulatory standards especially if it's coming from big countries. Investors are most likely to invest if they see that there are certain qualities and good behaviors to prove that their investments are secured (Greenhill, et al., 2009). The only challenge to the countries that adopted community development into their mining laws is the impact of the implementation (Dupuy, 2014).

The mandated community development program of mining companies has been in place for many countries and continues to be implemented to others in order to ensure that they are doing their social responsibility to the affected communities (Dupuy, 2014). These norms actually became a trend through the number of international initiatives, such as the environmental excellence exploration (E3), extractives industries initiative (EITI), global reporting initiative (GRI), ISO26000 and ISO 140000 (Dupuy, 2014).

\section{Research and Methodology}

The study utlilized the mixed-method approach design, using both qualitative and quantitative analyses. According to Creswell (2003), the mixed-method approach bases the inquiry on the assumption that collecting diverse types of data best provides an understanding of a research problem. The quantitative approach used the descriptive correlational method. 
The quantitative part of the research has subjected 376 respondents into answering a self made questionnaire which was tested for validity and reliability tests prior to distribution. The results were analyzed using SPSS. On the other hand, the qualitative approach used interview and focused group discussion; the results of which were used to validate the findings of the quantitative approach.

\section{Result and Discussion}

The research aimed to answer two important questions that relate to the research topic. The first questions measured the level of awareness of the respondents with regard to the social development and management programs implemented by the mining companies. Whereas, the second question assessed the perception of the respondents on the sustainability of the social development and management programs of the mining companies.

The following are specific questins and the results of the quantitative method, to wit:

What is the level of awareness of thecommunities about the Social Development and Management Programs of the mining companies in terms of the following accredited programs/projects/activities under the CDAO-2010-21:

-Human Resource Development; Enterprise Development; Assistance to Infrastructure Development; Access to Education; Access to Health Services; and Protections to respect of Socio-Cultural Values

Table 1: Percentage of respondent who are aware of social development and management programs of mining companies

\begin{tabular}{|c|c|c|c|c|c|c|c|c|c|c|c|c|}
\hline \multirow{3}{*}{$\begin{array}{l}\text { Social Development } \\
\text { and Management Programs }\end{array}$} & \multirow{2}{*}{\multicolumn{2}{|c|}{$\begin{array}{l}\text { CAMP } 3 \\
\mathrm{~N}=45\end{array}$}} & \multirow{2}{*}{\multicolumn{2}{|c|}{$\begin{array}{l}\text { DIDIPIO } \\
\mathbf{N}=\mathbf{2 1}\end{array}$}} & \multirow{2}{*}{\multicolumn{2}{|c|}{$\begin{array}{l}\text { MINUYAN } \\
\mathbf{N}=54\end{array}$}} & \multirow{2}{*}{\multicolumn{2}{|c|}{$\begin{array}{l}\text { SAN ROQUE } \\
\mathbf{N}=\mathbf{2 1 2}\end{array}$}} & \multirow{2}{*}{\multicolumn{2}{|c|}{$\begin{array}{l}\text { MATICTIC } \\
\mathrm{N}=\mathbf{4 4}\end{array}$}} & \multirow{2}{*}{\multicolumn{2}{|c|}{$\begin{array}{l}\text { Overall } \\
\mathbf{N}=376\end{array}$}} \\
\hline & & & & & & & & & & & & \\
\hline & Yes & No & Yes & No & Yes & No & Yes & No & Yes & No & Yes & No \\
\hline \multicolumn{13}{|l|}{$\begin{array}{ll}\text { Human } & \text { Resources } \\
\text { Development } & \\
\end{array}$} \\
\hline \multicolumn{13}{|l|}{ Capacity Building on: } \\
\hline Project Development & 62.2 & & & 0 & 100 & 0 & 63.7 & 36.3 & 68.2 & 31.8 & 71.3 & 28.7 \\
\hline Organizational Development & 100 & & & 71.4 & 100 & 0 & 70.3 & 29.7 & 68.2 & 31.8 & 75.5 & 24.5 \\
\hline Entrepreneurship & 100 & 0 & 9.5 & 37.8 & 100 & 25.9 & 16.0 & 84.0 & 84.1 & 15.9 & 42.0 & 58.0 \\
\hline Skills Development & 100 & 0 & 14.3 & 0 & 28.6 & 63.0 & 56.1 & 43.9 & 100 & 0 & 61.4 & 38.6 \\
\hline \multicolumn{13}{|l|}{$\begin{array}{l}\text { Enterprise Development and } \\
\text { Networking }\end{array}$} \\
\hline \multicolumn{13}{|l|}{ Income Generating Activities: } \\
\hline Animal Husbandry & 64.4 & 35.6 & 9.5 & 90.5 & 70.4 & 29.6 & 20.8 & 79.2 & 52.3 & 47.7 & 36.2 & 63.8 \\
\hline Provision of Farm Implements & 68.9 & 31.1 & 9.5 & 90.5 & 66.7 & 33.3 & 26.4 & 73.6 & 68.2 & 31.8 & 41.2 & 58.8 \\
\hline $\begin{array}{l}\text { Establishment of Micro- } \\
\text { Businesses }\end{array}$ & 17.8 & 82.2 & 9.5 & 90.5 & 70.4 & 29.6 & 9.9 & 90.1 & 86.4 & 13.6 & 28.5 & 71.5 \\
\hline Cooperative Development & 37.8 & 62.2 & 42.9 & 57.1 & 55.6 & 44.4 & 15.6 & 84.4 & 100 & 0 & 35.4 & 64.6 \\
\hline $\begin{array}{lll}\begin{array}{l}\text { Market linkages and } \\
\text { networking }\end{array} & & \\
\end{array}$ & 35.6 & 64.4 & 4.8 & 95.2 & 11.1 & 88.9 & 8.5 & 91.5 & 29.5 & 70.5 & 14.4 & 85.6 \\
\hline $\begin{array}{l}\text { Assistance to Infrastructure } \\
\text { Development and Support } \\
\text { Services }\end{array}$ & & & & & & & & & & & & \\
\hline \multicolumn{13}{|l|}{$\begin{array}{l}\text { Stimulating and Facilitating } \\
\text { other forms of } \\
\text { Economic Activity: such as } \\
\text { development, } \\
\text { construction, improvement } \\
\text { and maintenance of: }\end{array}$} \\
\hline Farm-to-market roads & 20.0 & 80.0 & 100 & 0 & 31.5 & 68.5 & 34.0 & 66.0 & 47.7 & 52.3 & 37.2 & 62.8 \\
\hline Water systems & 4.4 & 95.6 & 4.8 & 95.2 & 20.4 & 79.6 & 29.2 & 70.8 & 56.8 & 43.2 & 26.9 & 73.1 \\
\hline Post-harvest facilities & 22.2 & 77.8 & 14.3 & 85.7 & 27.8 & 72.2 & 27.4 & 72.6 & 79.5 & 20.5 & 32.2 & 67.8 \\
\hline Bridges & 100 & 0 & 100 & 0 & 0 & 100 & 24.1 & 75.9 & 79.5 & 20.5 & 40.4 & 59.6 \\
\hline Electricity & 48.9 & 51.1 & 100 & 0 & 53.7 & 46.3 & 51.9 & 48.1 & 52.3 & 47.7 & 48.9 & 51.1 \\
\hline
\end{tabular}


Table 1 shows the percentage of respondents who were aware of Social Development and Management Programs of Mining Companies implemented in the communities.

In terms of the Human Resources Development projects, $75.5 \%$ or 284 out of 376 respondents were aware that the mining company provides organizational development. And $71.3 \%$ of the respondents were awareof the Project Development provided by the Mining Companies.

Among the Enterprise Development and Networking projects only41.2\% of the respondents were aware of the Provision of Farm Implements.

In terms of Assistance to Infrastructure Development, only $48.9 \%$ of the respondents were aware that "electricity" was one of the projects of the Mining Companies. In terms of Access to Education and Educational Support Programs, 66\% of the respondents were aware that the mining companies provide educational opportunitiesand $57.2 \%$ were also aware that the companies provide construction and repair of school buildings for the community.

Table 2: Percentage of Respondent who are Aware of the Social Development and Management Programs of Mining Companies

\begin{tabular}{|c|c|c|c|c|c|c|c|c|c|c|c|c|}
\hline \multirow{3}{*}{$\begin{array}{l}\text { Social Development } \\
\text { Management Programs }\end{array}$} & \multicolumn{2}{|c|}{ CAMP 3} & \multicolumn{2}{|c|}{ DIDIPIO } & \multicolumn{2}{|c|}{ MINUYAN } & \multicolumn{2}{|c|}{ SAN ROQUE } & \multicolumn{2}{|c|}{ MATICTIC } & \multicolumn{2}{|c|}{ Overall } \\
\hline & \multicolumn{2}{|l|}{$N=45$} & \multicolumn{2}{|l|}{$\mathbf{N}=$} & \multicolumn{2}{|l|}{$\mathbf{N}=$} & \multicolumn{2}{|l|}{$\mathbf{N}=$} & \multicolumn{2}{|l|}{$\mathbf{N}=$} & \multicolumn{2}{|c|}{$N=376$} \\
\hline & Yes & No & Yes & No & Yes & Yes & Yes & No & Yes & No & Yes & No \\
\hline \multicolumn{13}{|l|}{$\begin{array}{l}\text { Access to Education and } \\
\text { Educational Support Programs }\end{array}$} \\
\hline $\begin{array}{ll}\text { Providing } & \text { Educational } \\
\text { opportunities } & \end{array}$ & & & & & & & & & & & & \\
\hline $\begin{array}{l}\text { Scholarship from primary to tertiary } \\
\text { education }\end{array}$ & 100 & 0 & 100 & 0 & 100 & 0 & 39.6 & 60.4 & 100 & 0 & 66.0 & 34.0 \\
\hline $\begin{array}{l}\text { Provision of apprenticeship } \\
\text { programs }\end{array}$ & 100 & 0 & 9.5 & 90.5 & 0 & 100 & 12.7 & 87.3 & 52.3 & 47.7 & 25.8 & 74.2 \\
\hline $\begin{array}{l}\text { Construction and Repair of school } \\
\text { buildings }\end{array}$ & 100 & 0 & 100 & 0 & 100 & 0 & 27.4 & 72.6 & 84.1 & 15.9 & 57.2 & 42.8 \\
\hline Subsidy for Teachers & 100 & 0 & 100 & 0 & 0 & 100 & 37.7 & 62.3 & 0 & 100 & 21.3 & 78.7 \\
\hline \multicolumn{13}{|l|}{$\begin{array}{l}\text { Access to Health Services, } \\
\text { Facilities and professionals }\end{array}$} \\
\hline \multicolumn{13}{|l|}{$\begin{array}{l}\text { Improving the living Conditions } \\
\text { and Health }\end{array}$} \\
\hline Provision of health facilities & 46.7 & 53.3 & 38.1 & 61.9 & 100 & 0 & 76.9 & 23.1 & 77.3 & 22.7 & 74.5 & 25.5 \\
\hline $\begin{array}{l}\text { Access to health services, medicines } \\
\text { and } \\
\quad \text { professionals }\end{array}$ & 100.0 & 0 & 28.6 & 71.4 & 100 & 0 & 66.0 & 34.0 & 79.5 & 20.5 & 74.5 & 25.5 \\
\hline $\begin{array}{l}\text { Health education and preventive } \\
\text { measures training }\end{array}$ & 51.1 & 48.9 & 57.1 & 42.9 & 100 & 0 & 24.5 & 75.5 & 79.5 & 20.5 & 46.8 & 53.2 \\
\hline Provision of health insurance & 0 & 100 & 0 & 100 & 0 & 100 & 43.3 & 56.5 & 0 & 100 & 24.5 & 75.5 \\
\hline Access to clean and potable water & 20.0 & 80.0 & 0 & 100 & 50.0 & 50.0 & 39.2 & 60.8 & 88.6 & 11.4 & 42.0 & 58.0 \\
\hline $\begin{array}{l}\text { Provision of waste and sewage } \\
\text { disposalfacilities }\end{array}$ & 97.8 & 2.2 & 19.0 & 81.0 & 42.6 & 57.4 & 48.6 & 51.4 & 40.9 & 59.1 & 51.1 & 48.9 \\
\hline \multicolumn{13}{|l|}{$\begin{array}{l}\text { Protection and Respect of Socio- } \\
\text { Cultural Values }\end{array}$} \\
\hline \multicolumn{13}{|l|}{$\begin{array}{l}\text { Safeguarding the Existing Socio- } \\
\text { Cultural } \\
\quad \text { Values }\end{array}$} \\
\hline $\begin{array}{l}\text { Special funding for religious } \\
\text { activities }\end{array}$ & 66.7 & 33.3 & 0 & 100 & 44.4 & 55.6 & 68.9 & 31.1 & 31.8 & 68.2 & 56.9 & 43.1 \\
\hline Promotion of Cultural Awareness & 51.1 & 48.9 & 76.2 & 23.8 & 22.2 & 77.8 & 65.6 & 34.4 & 22.7 & 77.3 & 53.2 & 46.8 \\
\hline
\end{tabular}

As for Access to Health Services, Facilities and professionals, $\mathbf{7 4 . 5 \%}$ of the respondents were aware that the mining companies provide health facilities and access to health services, medicines and professionals. $51.1 \%$ of the respondents were also aware that the company provide waste and sewage disposal facilities. 
In terms of Protection and Respect of Socio-Cultural Values, 56.9\% of the respondents were aware that the mining companies provide special funding for religious activitiesand 53.2\% were also aware that the companies provide promotion for Cultural Awareness.

As a validation of the quantitative results, the interview and FGD outcomes revealed that the respondents are aware of the social development and management programs of the mining companies operating in their communities. In regard to Human Resources Development projects, there is a high level of awareness of the training programs implemented such as training for women's skills, specifically, sewing, farming/gardening, and cosmetology. As far as Enterprise Development and Networking projects are concerned, the very low awareness of the projects under enterprise development and networking as highlighted in the quantitative method relates to the interview and FGD results which made mention that the established cooperatives in their communities were not maintained resulting to the closures of the cooperatives. As to Assistance to Infrastructure Development, the respondents are highly aware that the infrastructure projects built in their communities were projects of the mining companies.

In terms of Access to Education and Educational Support Programs, the respondents are aware on the existence of scholarship and internship programs and construction/repair of school facilities. About $75 \%$ of the respondents however mentioned that there is no available subsidies given to teachers.

As for Access to Health Services, Facilities and professionals, there is a high level of awareness among the respondents that the mining companies provide free medicines and medical services. It was noted also that the respondents are aware on the medical facilities funded by the mining companies in their respective communities.

Lastly for Protection and Respect of Socio-Cultural Values, the mining companies sponsor events such as community fiestas, rituals, and the like.

What is the perception of the respondents on the sustainability of the Social Development and Management Programs of the mining companies in terms of:

Stakeholder Groups Relationship; Company Financial and Management Capacity; and Compliance with the Legal Requirements

Table 3: Summary of the level of agreement on the sustainability of the social development and management programs of the mining companies in terms of stakeholders group relations.

\begin{tabular}{|c|c|c|c|c|c|c|c|c|c|c|c|c|}
\hline \multirow{3}{*}{$\begin{array}{l}\text { Stakeholder } \\
\text { Relationship }\end{array}$} & \multicolumn{2}{|c|}{ CAMP 3} & \multicolumn{2}{|c|}{ DIDIPIO } & \multicolumn{2}{|c|}{ MINUYAN } & \multicolumn{2}{|c|}{ SAN ROQUE } & \multicolumn{2}{|c|}{ MATICTIC } & \multicolumn{2}{|c|}{ Overall } \\
\hline & \multicolumn{2}{|l|}{$N=45$} & \multicolumn{2}{|l|}{$N=21$} & \multicolumn{2}{|l|}{$N=54$} & \multicolumn{2}{|c|}{$N=212$} & \multicolumn{2}{|l|}{$N=44$} & \multicolumn{2}{|c|}{$N=376$} \\
\hline & Mean & SD & Mean & SD & Mean & SD & Mean & SD & Mean & SD & Mean & SD \\
\hline \multicolumn{13}{|l|}{ Before SDMP } \\
\hline $\begin{array}{l}\text { The Company identified } \\
\text { stakeholder groups located } \\
\text { in the Mining Project. }\end{array}$ & $\begin{array}{l}2.18 \\
\text { A }\end{array}$ & .576 & $\begin{array}{l}1.76 \\
\text { A }\end{array}$ & .436 & $\begin{array}{l}1.83 \\
\mathrm{~A}\end{array}$ & .986 & $\begin{array}{l}1.82 \\
\mathrm{~A}\end{array}$ & .861 & $\begin{array}{l}2.32 \\
\mathrm{~A}\end{array}$ & .708 & $\begin{array}{l}1.92 \\
\mathrm{~A}\end{array}$ & .833 \\
\hline $\begin{array}{l}\text { There are social issues } \\
\text { raised against the Mining } \\
\text { Project. }\end{array}$ & $\begin{array}{l}1.00 \\
\text { SA }\end{array}$ & .000 & $\begin{array}{l}1.52 \\
\text { S } \\
\text { AA }\end{array}$ & .512 & $\begin{array}{l}1.00 \\
\text { SA }\end{array}$ & .000 & $\begin{array}{l}1.41 \\
\text { SA }\end{array}$ & .722 & $\begin{array}{l}1.45 \\
\text { SA }\end{array}$ & .504 & $\begin{array}{l}1.31 \\
\text { SA }\end{array}$ & .607 \\
\hline $\begin{array}{l}\text { The Company responded to } \\
\text { the issues raised to them. }\end{array}$ & $\begin{array}{l}1.38 \\
\text { SA }\end{array}$ & .576 & $\begin{array}{l}2.00 \\
\mathrm{~A}\end{array}$ & .000 & $\begin{array}{l}2.50 \\
D\end{array}$ & 1.077 & $\begin{array}{l}2.04 \\
\text { A }\end{array}$ & .753 & $\begin{array}{l}2.59 \\
D\end{array}$ & .497 & $\begin{array}{l}2.09 \\
\text { A }\end{array}$ & .818 \\
\hline $\begin{array}{l}\text { The stakeholder groups are } \\
\text { satisfied with the process. }\end{array}$ & $\begin{array}{l}2.71 \\
D\end{array}$ & .458 & $\begin{array}{l}3.57 \\
\text { SD }\end{array}$ & .598 & $\begin{array}{l}2.70 \\
D\end{array}$ & .662 & $\begin{array}{l}2.46 \\
\mathrm{~A}\end{array}$ & .955 & $\begin{array}{l}2.68 \\
D\end{array}$ & .601 & $\begin{array}{l}2.61 \\
D\end{array}$ & .854 \\
\hline \multicolumn{13}{|l|}{ SDMP Proceeding } \\
\hline $\begin{array}{l}\text { The stakeholder groups are } \\
\text { properly informed of the } \\
\text { Company SDMP }\end{array}$ & $\begin{array}{l}2.73 \\
D\end{array}$ & .447 & $\begin{array}{l}3.00 \\
D\end{array}$ & .707 & $\begin{array}{l}3.13 \\
D\end{array}$ & .912 & $\begin{array}{l}2.34 \\
\text { A }\end{array}$ & .790 & $\begin{array}{l}2.39 \\
\mathrm{~A}\end{array}$ & .754 & $\begin{array}{l}2.54 \\
D\end{array}$ & .822 \\
\hline $\begin{array}{l}\text { The stakeholder groups are } \\
\text { involved in the development } \\
\text { of the SDMP }\end{array}$ & $\begin{array}{l}1.80 \\
\mathrm{~A}\end{array}$ & .694 & $\begin{array}{l}3.24 \\
D\end{array}$ & .768 & $\begin{array}{l}1.91 \\
\mathrm{~A}\end{array}$ & 1.051 & $\begin{array}{l}2.14 \\
\text { A }\end{array}$ & .921 & $\begin{array}{l}2.18 \\
\mathrm{~A}\end{array}$ & .756 & $\begin{array}{l}2.13 \\
\mathrm{~A}\end{array}$ & .936 \\
\hline $\begin{array}{l}\text { The stakeholder groups are } \\
\text { satisfied with the Company } \\
\text { SDMP }\end{array}$ & $\begin{array}{l}2.18 \\
\text { A }\end{array}$ & .387 & $\begin{array}{l}2.86 \\
D\end{array}$ & .727 & $\begin{array}{l}1.80 \\
\mathrm{~A}\end{array}$ & .855 & $\begin{array}{l}1.71 \\
\text { SA }\end{array}$ & .752 & $\begin{array}{l}2.43 \\
\mathrm{~A}\end{array}$ & .695 & $\begin{array}{l}1.93 \\
\text { A }\end{array}$ & .798 \\
\hline $\begin{array}{l}\text { There are major social } \\
\text { issues raised against the } \\
\text { SDMP }\end{array}$ & $\begin{array}{l}1.00 \\
\text { SA }\end{array}$ & .000 & $\begin{array}{l}1.00 \\
\text { SA }\end{array}$ & 0.000 & $\begin{array}{l}1.96 \\
\text { A }\end{array}$ & .846 & $\begin{array}{l}2.30 \\
\text { A }\end{array}$ & 1.076 & $\begin{array}{l}1.77 \\
\text { A }\end{array}$ & .859 & $\begin{array}{l}1.96 \\
\text { A }\end{array}$ & 1.033 \\
\hline $\begin{array}{l}\text { The Company addressed the } \\
\text { social issues raised against } \\
\text { the SDMP. }\end{array}$ & $\begin{array}{l}2.22 \\
\text { A }\end{array}$ & .704 & $\begin{array}{l}3.19 \\
D\end{array}$ & .512 & $\begin{array}{l}2.31 \\
\text { A }\end{array}$ & .886 & $\begin{array}{l}2.02 \\
\text { A }\end{array}$ & .823 & $\begin{array}{l}2.32 \\
\text { A }\end{array}$ & .639 & $\begin{array}{l}2.19 \\
\text { A }\end{array}$ & .829 \\
\hline $\begin{array}{l}\text { The stakeholder groups are } \\
\text { satisfied with the actions } \\
\text { taken by the Company }\end{array}$ & $\begin{array}{l}3.00 \\
D\end{array}$ & 0.000 & $\begin{array}{l}3.19 \\
D\end{array}$ & .512 & $\begin{array}{l}2.54 \\
D\end{array}$ & .693 & $\begin{array}{l}1.96 \\
\text { A }\end{array}$ & .793 & $\begin{array}{l}2.25 \\
\mathrm{~A}\end{array}$ & .751 & $\begin{array}{l}2.27 \\
\text { A }\end{array}$ & .823 \\
\hline
\end{tabular}


Table 3 shows the summary of the level of agreement on the sustainability of the social development and management programs of the mining companies in terms of stakeholder groups relationship before SDMP. The results revealed that the respondents of the five Barangays have strongly agreed that "there are social issues raised against the mining project" but they disagreed on "the stakeholder groups are satisfied with the process."

In terms of stakeholder groups relationship on SDMP proceeding, results showed that the respondents from the five Barangays agreed on the SDMP proceeding except on one item which is "the stakeholder groups are properly informed of the Company SDMP."

The results of the FGD and interview confirmed the results generated by the survery questionnaire. In summary, the qualitative method results confirmed the following:
i. $\quad$ Before SMDP, all respondents strongly agreed that there are social issues such as forced relocation of the community; low quality of water; not enough electricity; human rights violations.
ii. $\quad$ The respondents disagreed that they are satisfied with the actions taken by the mining companies with regard to the process implemented.

However, the FGD and interview findings did not confirm the result of the quantitative method which confirmed that they respondents disagreed that he stakeholder groups are properly informed of the Company SDMP. The qualitative method found that the all respondents strongly agreed that the Company identified groups in the community.

In the case of SDMP proceeding, the qualitative method results revealed conflicting findings when compared to the results of the quantitative method. The FGD and interview found the following:
i. $\quad$ Not all respondents agree that they were involved in the development of the SMDP.
ii. $\quad$ The mining companies have addressed the concerns raised.
iii. The respondents are satisfied with how the mining companies have addressed their social concerns.

On the other hand, the FGD and interveiw results found that the stakeholder groups are not properly informed of the company SDMP. This confirms the finding of the quantitative results that the respondents have disagreed (2.54) that they were informed of the SMDP programs of the mining companies.

Table 4: Summary of the level of agreement on the sustainability of the social development and management programs of the mining companies in terms of company financial and management capacity.

\begin{tabular}{|c|c|c|c|c|c|c|c|c|c|c|c|c|}
\hline \multirow{3}{*}{$\begin{array}{l}\text { Company Financial } \\
\text { Management Capacity }\end{array}$} & \multicolumn{2}{|c|}{ CAMP 3} & \multirow{2}{*}{$\begin{array}{l}\text { DIDIPIO } \\
\mathbf{N}=\mathbf{2 1}\end{array}$} & \multicolumn{3}{|c|}{ MINUYAN } & \multicolumn{2}{|c|}{ SAN ROQUE } & \multicolumn{2}{|c|}{ MATICTIC } & \multicolumn{2}{|c|}{ Overall } \\
\hline & \multicolumn{2}{|l|}{$N=45$} & & \multicolumn{3}{|c|}{$N=54$} & \multicolumn{2}{|c|}{$N=212$} & \multicolumn{2}{|l|}{$N=44$} & \multicolumn{2}{|c|}{$\mathrm{N}=376$} \\
\hline & Mean & SD & Mean & SD & Mean & SD & Mean & SD & Mean & SD & Mean & SD \\
\hline $\begin{array}{l}\text { The Company } 1.5 \% \text { budget for } \\
\text { SDMP enough to implement the } \\
\text { programs/Projects/Activities for } \\
\text { the host community }\end{array}$ & 2.18 & .576 & 1.76 & .436 & 1.83 & .986 & 1.82 & .861 & 2.32 & .708 & $\begin{array}{l}1.92 \\
\mathrm{~A}\end{array}$ & .833 \\
\hline $\begin{array}{l}\text { The Company have adequate staff } \\
\text { to manage the SDMP. }\end{array}$ & 1.00 & .000 & 1.52 & .512 & 1.00 & .000 & 1.41 & .722 & 1.45 & .504 & $\begin{array}{l}1.31 \\
\text { SA }\end{array}$ & .607 \\
\hline $\begin{array}{l}\text { The staff possess } \\
\text { professional and } \\
\text { background. }\end{array}$ & 1.38 & .576 & 2.00 & .000 & 2.50 & 1.077 & 2.04 & .753 & 2.59 & .497 & $\begin{array}{l}2.09 \\
\text { A }\end{array}$ & .818 \\
\hline $\begin{array}{l}\text { There are complete set of SDMP } \\
\text { documents in the Office. }\end{array}$ & 2.71 & .458 & 3.57 & .598 & 2.70 & .662 & 2.46 & .955 & 2.68 & .601 & $\begin{array}{l}2.61 \\
D\end{array}$ & .854 \\
\hline $\begin{array}{l}\text { There is an established procedure } \\
\text { for the SDMP implementation }\end{array}$ & 2.73 & .447 & 3.00 & .707 & 3.13 & .912 & 2.34 & .790 & 2.39 & .754 & $\begin{array}{l}2.54 \\
D\end{array}$ & .822 \\
\hline $\begin{array}{l}\text { There is an established financial } \\
\text { procedure in the processing of the } \\
\text { P/P/As of the SDMP. }\end{array}$ & 1.80 & .694 & 3.24 & .768 & 1.91 & 1.051 & 2.14 & .921 & 2.18 & .756 & $\begin{array}{l}2.13 \\
\mathrm{~A}\end{array}$ & .936 \\
\hline $\begin{array}{l}\text { There is an established monitoring } \\
\text { system for the P/P/As of the SDMP. }\end{array}$ & 2.18 & .387 & 2.86 & .727 & 1.80 & .855 & 1.71 & .752 & 2.43 & .695 & $\begin{array}{l}1.93 \\
\mathrm{~A}\end{array}$ & .798 \\
\hline
\end{tabular}

In terms of Company Capability, theresults revealed that the respondents have agreed strongly that "the Company has adequate staff to manage the SDMP" but they disagreed on two items, firstly, that "there are complete set of SDMP documents in the Office" and secondly, that "there is an established procedure for the SDMP implementation." 
Meanwhile the results of the qualititative method confirmed the findings of the quantitative method, to wit:

i. $\quad$ The respondents are aware of the $1.5 \%$ budget of mining companies for SMDP.

ii. $\quad$ The mining companies have adequate staff to run the SMPD projects of the mining companies.

iii. The personnel of the mining companies running the SMDP projects shows professionalism.

$i v$. The mining companies have incomplete set of SMDP documents kept in their offices.

However, there were conflicting findings with respect to established procedures in SMDP implementation and monitoring since FGD and interview respondents have varied answers which are totally different from the results of the quantitative method.

Table 5: Summary of the level of agreement on the sustainability of the social development and management programs of the mining companies in terms of adherence to the legal requirements (P/P/A Dev't).

\begin{tabular}{|c|c|c|c|c|c|c|c|c|c|c|c|c|}
\hline \multirow{3}{*}{$\begin{array}{l}\text { Adherence to the Legal } \\
\text { Requirements }\end{array}$} & \multirow{3}{*}{$\begin{array}{l}\text { CAMP } \\
\mathbf{3} \\
\mathbf{N}=\mathbf{4 5} \\
\text { Mean }\end{array}$} & \multicolumn{2}{|c|}{ DIDIPIO } & \multicolumn{2}{|c|}{ MINUYAN } & \multicolumn{2}{|c|}{ SAN ROQUE } & \multicolumn{2}{|c|}{ MATICTIC } & \multicolumn{3}{|c|}{ Overall } \\
\hline & & \multicolumn{2}{|c|}{$\mathbf{N}=\mathbf{2 1}$} & \multicolumn{2}{|c|}{$N=54$} & \multicolumn{2}{|c|}{$\mathrm{N}=212$} & \multicolumn{2}{|c|}{$N=44$} & \multicolumn{3}{|c|}{$N=376$} \\
\hline & & SD & Mean & SD & Mean & SD & Mean & SD & Mean & SD & Mean & SD \\
\hline \multicolumn{13}{|l|}{ 1. P/P/A Development } \\
\hline $\begin{array}{l}\text { The Company based its budgetary } \\
\text { allocation on the previous year's } \\
\text { Operating Cost as prescribed by } \\
\text { Law. }\end{array}$ & 1.00 & .000 & 1.00 & .000 & 1.00 & .000 & 2.41 & .573 & 1.52 & .698 & $\begin{array}{l}1.86 \\
\mathrm{~A}\end{array}$ & .814 \\
\hline $\begin{array}{l}\text { The sectors of the host communities } \\
\text { were consulted based on their } \\
\text { needs, interest and capacities. }\end{array}$ & 2.07 & .688 & 2.10 & .436 & 2.37 & .708 & 2.12 & .450 & 1.80 & .594 & $\begin{array}{l}2.11 \\
\mathrm{~A}\end{array}$ & .559 \\
\hline $\begin{array}{l}\text { The Company submitted complete } \\
\text { documents as required by the Law. }\end{array}$ & 1.71 & .626 & 1.43 & .507 & 2.76 & 1.06 & 2.33 & .553 & 2.59 & .497 & $\begin{array}{l}2.30 \\
\mathrm{~A}\end{array}$ & .738 \\
\hline $\begin{array}{l}\text { The Company submitted all the } \\
\text { documentary requirements on time. }\end{array}$ & 1.89 & .647 & 1.86 & .478 & 2.41 & .836 & 2.71 & .903 & 2.48 & .505 & $\begin{array}{l}2.49 \\
\text { A }\end{array}$ & .861 \\
\hline $\begin{array}{l}\text { The Company adhered to the } \\
\text { required substance and form of the } \\
\text { documents submitted. }\end{array}$ & 2.20 & .757 & 1.52 & .512 & 2.78 & 1.18 & 2.40 & .718 & 2.48 & .505 & $\begin{array}{l}2.39 \\
\text { A }\end{array}$ & .815 \\
\hline $\begin{array}{l}\text { The Identified } \\
\text { programs/projects/activities are } \\
\text { based on the community needs. }\end{array}$ & 2.89 & .885 & 2.76 & .700 & 2.76 & .989 & 2.34 & .918 & 2.48 & .731 & $\begin{array}{l}2.51 \\
D\end{array}$ & .915 \\
\hline $\begin{array}{l}\text { The } \\
\text { programs/projects/activities ofthe } \\
\text { SDMP produced general } \\
\text { community interest. }\end{array}$ & 1.78 & .420 & 1.52 & .512 & 2.74 & 1.12 & 2.72 & .812 & 1.00 & 0.00 & $\begin{array}{l}2.34 \\
\mathrm{~A}\end{array}$ & .986 \\
\hline $\begin{array}{l}\text { The programs/projects/activities of } \\
\text { the SDMP encouraged the } \\
\text { community involvement for its } \\
\text { implementation. }\end{array}$ & 1.00 & .000 & 1.24 & .436 & 1.94 & .564 & 1.92 & .625 & 1.89 & .722 & $\begin{array}{l}1.77 \\
\mathrm{~A}\end{array}$ & .663 \\
\hline $\begin{array}{l}\text { The Company signed a } \\
\text { Memorandum of Agreement } \\
\text { with the representative/s of the } \\
\text { community and LGU } \\
\text { in conjunction to the approved 5- } \\
\text { Year SDMP. }\end{array}$ & 2.24 & .484 & 1.00 & 0.00 & 1.78 & .538 & 1.92 & .634 & 1.52 & .505 & $\begin{array}{l}1.84 \\
\mathrm{~A}\end{array}$ & .632 \\
\hline $\begin{array}{l}\text { The Company provided a complete } \\
\text { set of approved documents to its } \\
\text { host and neighboring communities } \\
\text { and the LGU }\end{array}$ & 2.76 & .773 & 3.19 & .402 & 2.57 & .499 & 2.13 & .454 & 2.09 & .802 & $\begin{array}{l}2.32 \\
\mathrm{~A}\end{array}$ & .637 \\
\hline $\begin{array}{l}\text { The Company created, as part of its } \\
\text { operations, a Community Relations } \\
\text { Office for SDMP implementation. }\end{array}$ & 1.00 & 0.00 & 1.00 & 0.00 & 1.00 & 0.00 & 2.07 & .502 & 3.00 & 0.00 & $\begin{array}{l}1.84 \\
\mathrm{~A}\end{array}$ & .744 \\
\hline
\end{tabular}

Table 5 shows the summary of the level of agreement on the sustainability of the Social Development and Management Programs of the Mining Companies in terms of Adherence to the Legal Requirements specifically P/P/A development. The results showed that the respondents of the five Barangays agree to 10 out of 11 itemsbut they disagreed on the item that "the identified programs/projects/activities are based on the community needs." 
The qualitative approach supported the findings of the quantitative approach in 9/11 items. The FGD and intereview results differed in item that "the identified programs/projects/activities are based on the community needs" since the respondents of the qualitative approach registered their agreement that the mining companies based their SMDP projects from the needs of the host communities. Additionally, the respondents disagreed that the that the mining companies submitted complete set of documents of the SDMP and on time and that it adhered to the requirements set forth by the Government which is an exact opposite of the quantitative approach.

Table 6: Summary of the level of agreement on the sustainability of the social development and management programs of the mining companies in terms of adherence to the legal requirements ( $\mathrm{M} \& \mathrm{E}$ ).

\begin{tabular}{|c|c|c|c|c|c|c|c|c|c|c|c|c|}
\hline \multirow{3}{*}{$\begin{array}{l}\text { Adherence to the Legal } \\
\text { Requirements }\end{array}$} & \multicolumn{2}{|c|}{ CAMP 3} & \multicolumn{2}{|c|}{ DIDIPIO } & \multicolumn{2}{|c|}{ MINUYAN } & \multicolumn{2}{|c|}{ SAN ROQUE } & \multirow{2}{*}{\multicolumn{2}{|c|}{$\begin{array}{l}\text { MATICTI } \\
\text { C } \\
\mathbf{N}=\mathbf{4 4}\end{array}$}} & \multirow{2}{*}{\multicolumn{2}{|c|}{$\begin{array}{l}\text { Overall } \\
N=376\end{array}$}} \\
\hline & \multicolumn{2}{|c|}{$N=45$} & \multicolumn{2}{|c|}{$\mathbf{N}=\mathbf{2 1}$} & \multicolumn{2}{|c|}{$N=54$} & \multicolumn{2}{|c|}{$N=212$} & & & & \\
\hline & $\begin{array}{l}\text { Mea } \\
\text { n }\end{array}$ & SD & $\begin{array}{l}\text { Mea } \\
\text { n }\end{array}$ & SD & $\begin{array}{l}\text { Mea } \\
\text { n }\end{array}$ & SD & $\begin{array}{l}\text { Mea } \\
\text { n }\end{array}$ & SD & $\begin{array}{l}\text { Me } \\
\text { an }\end{array}$ & SD & $\begin{array}{l}\text { Me } \\
\text { an }\end{array}$ & SD \\
\hline \multicolumn{13}{|l|}{ Monitoring } \\
\hline $\begin{array}{l}\text { The monthly internal } \\
\text { monitoring was conducted } \\
\text { together with the host } \\
\text { community. }\end{array}$ & 2.56 & .841 & 3.05 & .498 & 2.35 & .649 & 2.67 & .539 & 2.43 & .728 & $\begin{array}{l}2.60 \\
D\end{array}$ & .637 \\
\hline $\begin{array}{l}\text { The quarterly monitoring } \\
\text { activity was conducted by } \\
\text { the MGB-RO together with } \\
\text { the company and host }\end{array}$ & 2.73 & .539 & 3.29 & .561 & 3.02 & .598 & 2.69 & .529 & 2.59 & .658 & $\begin{array}{l}2.77 \\
D\end{array}$ & .583 \\
\hline $\begin{array}{l}\text { The annual audit was } \\
\text { conducted by the MGB-CO } \\
\text { together with the Company } \\
\text { and host community. }\end{array}$ & 2.56 & .624 & 2.67 & .796 & 2.80 & .491 & 2.55 & .569 & 2.68 & .561 & $\begin{array}{l}2.61 \\
D\end{array}$ & .583 \\
\hline \multicolumn{13}{|l|}{ Evaluation } \\
\hline $\begin{array}{l}\text { The Social Impact } \\
\text { Assessment was conducted } \\
\text { hv the commanv to their }\end{array}$ & 1.58 & .499 & 1.86 & .359 & 2.67 & .476 & 2.59 & .613 & 2.00 & .647 & $\begin{array}{l}2.37 \\
\text { A }\end{array}$ & .688 \\
\hline $\begin{array}{l}\text { The programs, } \\
\text { projects/activities of the } \\
\text { SDMP contributed to the } \\
\text { socio-economic } \\
\text { develonment of the }\end{array}$ & 1.00 & $\begin{array}{l}0.00 \\
0\end{array}$ & 1.00 & $\begin{array}{l}0.00 \\
0\end{array}$ & 1.00 & $\begin{array}{l}0.00 \\
0\end{array}$ & 2.33 & .594 & 1.00 & $\begin{array}{l}0.00 \\
0\end{array}$ & $\begin{array}{l}1.75 \\
\text { A }\end{array}$ & .795 \\
\hline $\begin{array}{l}\text { There is a necessity for the } \\
\text { improvement of the } \\
\text { programs/projects/activities } \\
\text { to serve the needs } \\
\text { of the communities. }\end{array}$ & 4.00 & $\begin{array}{l}0.00 \\
0\end{array}$ & 4.00 & $\begin{array}{l}0.00 \\
0\end{array}$ & 3.00 & $\begin{array}{l}0.00 \\
0\end{array}$ & 4.00 & 0.000 & 1.00 & $\begin{array}{l}0.00 \\
0\end{array}$ & $\begin{array}{l}3.51 \\
\text { SD }\end{array}$ & .977 \\
\hline
\end{tabular}

Table 6 shows the summary of the level of agreement on the sustainability of the Social Development and Management Programs of the Mining Companies in terms of Adherence to the Legal Requirements specifically monitoring and evaluation. The results revealed that there is a strong disagreement on the item "there is a necessity for the improvement of the programs/projects/activities to serve the needs of the communities." There are only 2 items to which the respondents agreed; "the Social Impact Assessment was conducted by the company to their previous 5-Year SDMP" and "the programs, projects/activities of the SDMP contributed to the socio-economic development of the community."

There is however totally different results of the qualitative method since the respondents agreed in 5 out 6 items except for the item in which it asked whether there is an audit conducted.

\section{Conclusions}

The results of the study led to the conclusion that the host communities are aware on the SMDP projects of the mining companies as part of their corporate social responsibility programs. Also, the host communities believe that there are social issues raised that are not addressed by the mining companies. It is also conclusive that there is a strong agreement among the respondents that the SMDP projects are implemented but lacks audit procedures. Lastly, the host communities agreed that the SMDP projects are sustainable. 


\section{References}

Adonteng-Kissi, O. (2017). Poverty and mine's compensation package: Experiences of local farmers in Prestea mining community. Resources Policy, 52, 226-234. doi:10.1016/j.resourpol.2017.03.007

Arsel, M., Hogenboom, B., \& Pellegrini, L. (2016). The extractive imperative and the boom in environmental conflicts at the end of the progressive cycle in Latin America. The Extractive Industries and Society, 3(4), 877-879. doi:10.1016/j.exis.2016.10.013

Ballard, C.,\& Banks, G. (2003). Resource Wars: The Anthropology of Mining. Annual Review of Anthropology, 32(1), 287-313 doi:10.1146/annurev. anthro.32.061002.093116

Bebbington, A. J. (2014). Socio-environmental conflict: an opportunity for mining companies. Journal of Cleaner Production, 84, 34. doi:10.1016/j.jclepro.2014.08.108

CIEL-submits-brief-to-the-interamerican-commission-of-human-rights-on-access-to-information-regarding-gmos-febr-2010. (n.d.). Human Rights Documents online. doi:10.1163/2210-7975_hrd-9986-0010

Conde, M.,\& Billion, P. (2017). Resistance to mining. A Review. Ecological Economics, 132, 80-90. doi:10.1016/j.ecolecon.2016.08.025

Conde, M.,\& Billon, P. (2017). Why do some communities resist mining projects while others do not? The Extractive Industries and Society, 4(3), 681-697. doi:10.1016/j.exis.2017.04.009

Creswell, J. (2003). Research design: Qualitative, quantitative and mixed methods approaches (2nd ed.). Thousand Oaks, CA: SAGE Publications.

Corporate Social Responsibility: Implications for Small and Medium Enterprises in Developing Countries, United Nations Industrial Development Organization, (2002). http://www.unido.org/userfiles/BethkeK/csr.pdf (pdf file size 1.13mb).

Davis, G. A.,\& Vásquez Cordano, A. L. (2013). The fate of the poor in growing mineral and energy economies. Resources Policy, 38(2), 138-151. doi:10.1016/j.resourpol.2012.10.002

Dietz, K.,\& Engels, B. (2017). Contested extractivism, society and the state: An Introduction. Contested Extractivism, Society and the State, 1-19. doi:10.1057/978-1-137-58811-1_1

Dupuy, K. (2014). Community development requirements in mining laws. The Extractive Industries and Society. 1(2), $200-2015$. doi.org/10.1016/j.exis.2014.04.007

Essah, M.,\& Andrews, N. (2016). Linking or de-linking sustainable mining practices and corporate social responsibility? Insights from Ghana. Resources Policy, 50, 75-85. doi:10.1016/j.resourpol.2016.08.008

Fisher, E., Mwaipopo, R., Mutagwaba, W., Nyange, D., \& Yaron, G. (2009). “The ladder that sends us to wealth": Artisanal mining and poverty reduction in Tanzania. Resources Policy, 34(1-2), 32-38. doi:10.1016/j.resourpol.2008.05.003

Fox, S. (2015). History, violence, and the emergence of Guatemala's mining sector. Environmental Sociology, 1(3), 152-165 doi:10.1080/23251042.2015.1046204

Gamu, J., Le Billon, P., \& Spiegel, S. (2015). Extractive industries and poverty: A review of recent findings and linkage mechanisms. The Extractive Industries and Society, 2(1), 162-176. doi:10.1016/j.exis.2014.11.001

Ge, J.,\& Lei, Y. (2013). Mining development, income growth and poverty alleviation: A multiplier decomposition technique applied to China. Resources Policy, 38(3), 278-287. doi:10.1016/j.resourpol.2013.05.004

Govindan, K., Kannan, D., \& Shankar, K. M. (2014). Evaluating the drivers of corporate social responsibility in the mining industry with multi-criteria approach: A multi-stakeholder perspective. Journal of Cleaner Production, 84, $214-232$. doi:10.1016/j.jclepro.2013.12.065

Greenhill, et al., 2009. (n.d.). Investors are more likely to invest if they see that there are certain qualities and good behaviors to prove that their investments are secured. doi:10.1787/888933458242

Haslam, P. A.,\& Tanimoune, A. (2016). The determinants of social conflict in the Latin American mining sector: new evidence with quantitative data. World Development, 78, 401-419. doi:10.1016/j.worlddev.2015.10.020

Holden, W. N.,\& Jacobson, R. D. (2009). Ecclesial opposition to nonferrous mining in Guatemala: neoliberalism meets the church of the poor in a shattered society. The Canadian Geographer / Le Géographe canadien, 53(2), 145-164. doi:10.1111/j.15410064.2009.00251.x

Holden, W. N. (2015). Indigenous peoples and non-ferrous metals mining in the Philippines. The Pacific Review18(3), 417-438. doi:10.1080/09512740500189199

Owen, J. R.,\& Kemp, D. (2013). Social license and mining: A critical perspective. Resources Policy, 38(1), $29-35$. doi:10.1016/j.resourpol.2012.06.016

Martinez-Alier, J. (20013). Mining conflicts, environmental justice, and valuation. Journal of Hazardous Materials, 86(1-3), 153170. doi:10.1016/s0304-3894(01)00252-7

Muradian, R., Martinez-Alier, J., \& Correa, H. (2003). International capital versus local population: The environmental conflict of the tambogrande mining project, Peru. Society \& Natural Resources, 16(9), 775-792. doi:10.1080/08941920309166

Pérez Rincón, M. A. (2013). Conceptualización sobre el Desarrollo Sostenible: operacionalización del concepto para Colombia. PUNTO DE VISTA, 3(5). doi:10.15765/pdv.v3i5.137

Perreault, T. (2012). Dispossession by accumulation? Mining, water and the nature of enclosure on the Bolivian Altiplano. Antipode, no-no. doi:10.1111/anti.12005 
Prior, T., Giurco, D., Mudd, G., Mason, L., \& Behrisch, J. (2012). Resource depletion, peak minerals and the implications for sustainable resource management. GlobalEnvironmentalChange, 22(3)577-587. doi:10.1016/j.gloenvcha.2011.08.009

Robbins, P. (2003). Political ecology in political geography. Political Geography, 22(6), 641-645. doi:10.1016/s09626298(03)00071-4

Turker, D. (2018). Global Challenges: Aligning social responsibility and sustainable development goals. CSR, Sustainability, Ethics \& Governance, 161-176. doi:10.1007/978-3-319-91710-8_10

Wilson, S. A. (2015). Corporate social responsibility and power relations: Impediments to community development in post-war Sierra Leone diamond and rutile mining areas. The Extractive Industries and Society, 2(4), 704-713. doi:10.1016/j.exis.2015.09.002

Zamorshchikova, V. (2016). Mining and indigenous communicites: CSR practices of mining companies. 16th International Multidisciplinary Scientific GeoConference SGEM2016, Science and Technologies in Geology, Exploration and Mining. doi:10.5593/sgem2016/b12/s03.077 